Prepared in cooperation with the Afghanistan Geological Survey, Ministry of Mines under the auspices of the Task Force for Business and Stability Operations, Department of Defense

\title{
Technique for Estimation of Streamflow Statistics in Mineral Areas of Interest in Afghanistan
}

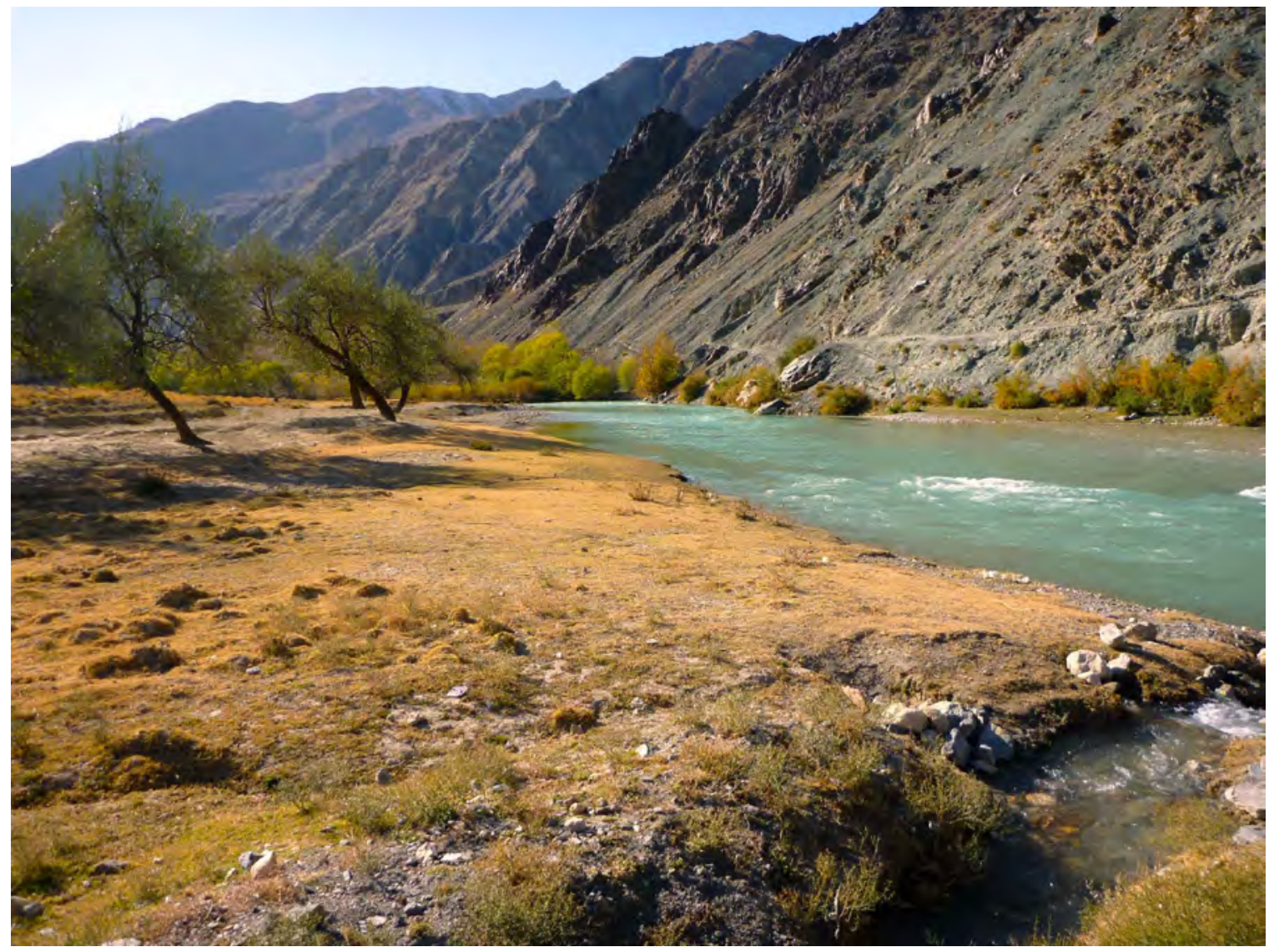

Open-File Report 2011-1176 
Cover. Photograph showing the Balkh River at Sari Puhl in northern Afghanistan. 


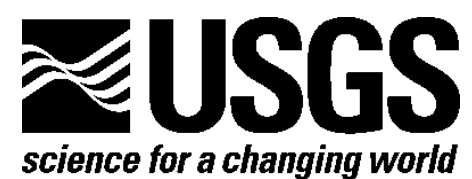

Prepared in cooperation with the Afghanistan Geological Survey, Ministry of Mines under the auspices of the Task Force for Business and Stability Operations, Department of Defense

\section{Technique for Estimation of Streamflow Statistics in Mineral Areas of Interest in Afghanistan}

By Scott A. Olson and Thomas J. Mack

Open-File Report 2011-1176

U.S. Department of the Interior

U.S. Geological Survey

USGS Afghanistan Project Product Number 232 


\section{U.S. Department of the Interior \\ KEN SALAZAR, Secretary}

\section{U.S. Geological Survey \\ Marcia K. McNutt, Director}

U.S. Geological Survey, Reston, Virginia 2011

For product and ordering information:

World Wide Web: http://www.usgs.gov/pubprod

Telephone: 1-888-ASK-USGS

For more information on the USGS-the Federal source for science about the Earth,

its natural and living resources, natural hazards, and the environment:

World Wide Web: http://www.usgs.gov

Telephone: 1-888-ASK-USGS

Suggested citation:

Olson, S.A., and Mack, T.J., 2011, Technique for estimation of streamflow statistics in mineral areas of interest in Afghanistan: U.S. Geological Survey Open-File Report 2011-1176, 17 p., at http://pubs.usgs.gov/of/2011/1176/.

Any use of trade, product, or firm names is for descriptive purposes only and does not imply endorsement by the U.S. Government.

Although this report is in the public domain, permission must be secured from the individual copyright owners to reproduce any copyrighted material contained within this report. 


\section{Contents}

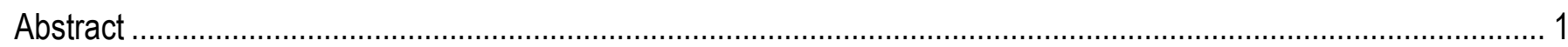

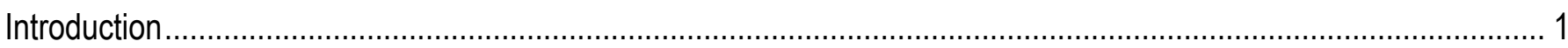

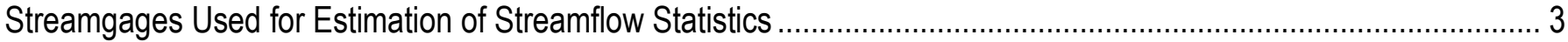

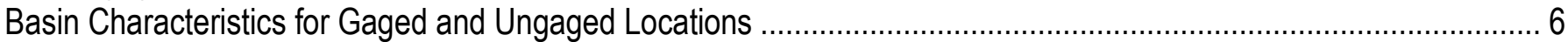

Estimation of Streamflow Statistics at Ungaged Locations ...........................................................................

Equations for Estimation of Streamflow Statistics at Ungaged Locations ..........................................................

Application of Streamflow Statistics at Ungaged Locations.........................................................................

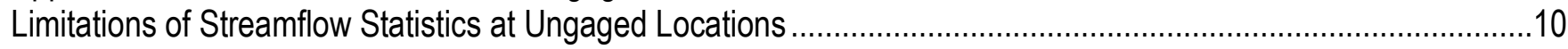

Summary

References Cited ...........................................................................................................................11

Appendix 1. Basin Characteristics for Streamgages Used for Estimation of Streamflow at Ungaged Locations in

Mineral Areas of Interest in Afghanistan.

\section{Figures}

Figure 1. Map showing historical streamgage locations and mineral areas of interest in Afghanistan

Figure 2. Graph showing drainage area verses daily streamflow exceeded 80 percent of the time (D80) for historical streamgages used in this investigation of mineral areas of interest in Afghanistan. 9

\section{Tables}

Table 1. Streamgages used for estimation of streamflow statistics in mineral areas of interest in Afghanistan 4

Table 2. Suggested drainage-area-ratio exponents for estimation of streamflow statistics in mineral areas of interest in Afghanistan 


\section{Conversion Factors and Datum}

\begin{tabular}{lcl}
\hline \multicolumn{1}{c}{ Multiply } & By & \multicolumn{1}{c}{ To obtain } \\
\hline millimeter $(\mathrm{mm})$ & Length & \\
meter $(\mathrm{m})$ & 0.03937 & inch (in.) \\
kilometer $(\mathrm{km})$ & 3.281 & foot (ft) \\
\hline & 0.6214 & mile (mi) \\
\hline square kilometer $\left(\mathrm{km}^{2}\right)$ & Area & \\
\hline & 0.3861 & square mile $\left(\mathrm{mi}^{2}\right)$ \\
\hline cubic meter $\left(\mathrm{m}^{3}\right)$ & Volume & \\
cubic meter $\left(\mathrm{m}^{3}\right)$ & 264.2 & gallon $($ gal) \\
& 35.31 & cubic foot $\left(\mathrm{ft}^{3}\right)$ \\
\hline cubic meter per second $\left(\mathrm{m}^{3} / \mathrm{s}\right)$ & Flow rate & \\
cubic meter per second $\left(\mathrm{m}^{3} / \mathrm{s}\right)$ & 70.07 & acre-foot per day $($ acre- $\mathrm{ft} / \mathrm{d})$ \\
\hline
\end{tabular}

Vertical and horizontal coordinate information is referenced to the World Geodetic System of 1984 (WGS 84). Elevation, as used in this report, refers to distance above the vertical datum. 


\title{
Technique for Estimation of Streamflow Statistics in Mineral Areas of Interest in Afghanistan
}

\author{
By Scott A. Olson and Thomas J. Mack
}

\begin{abstract}
A technique for estimating streamflow statistics at ungaged stream sites in areas of mineral interest in Afghanistan using drainage-area-ratio relations of historical streamflow data was developed and is documented in this report. The technique can be used to estimate the following streamflow statistics at ungaged sites: (1) 7-day low flow with a 10-year recurrence interval, (2) 7-day low flow with a 2-year recurrence interval, (3) daily mean streamflow exceeded 90 percent of the time, (4) daily mean streamflow exceeded 80 percent of the time, (5) mean monthly streamflow for each month of the year, (6) mean annual streamflow, and (7) minimum monthly streamflow for each month of the year. Because they are based on limited historical data, the estimates of streamflow statistics at ungaged sites are considered preliminary.

\section{Introduction}

Afghanistan has many mineral areas of interest (fig. 1) that may be a source of economic opportunity for the country (Peters and others, 2007; 2011). Water is needed both for mining processes and to support the communities and related industries that may develop around a mining economy. Mining activities generally require large volumes of processing water, which may be obtained most economically from surface-water sources. Estimates of streamflow statistics are needed to assess whether sufficient water is likely to be available in local streams at various times of the year for both mining and community needs. Streamflow statistics, based on data collected from the mid-1940s to 1980, are available for 150 of 174 historical streamgaging sites in Afghanistan that were operated by the Afghanistan Ministry of Energy and Water (Olson and Williams-Sether, 2010; Williams-Sether, 2008; Vining, 2010). In some mineral areas of interest, however, no historical gages are present (fig. 1); therefore, methods for estimating streamflow characteristics in these areas are needed.
\end{abstract}




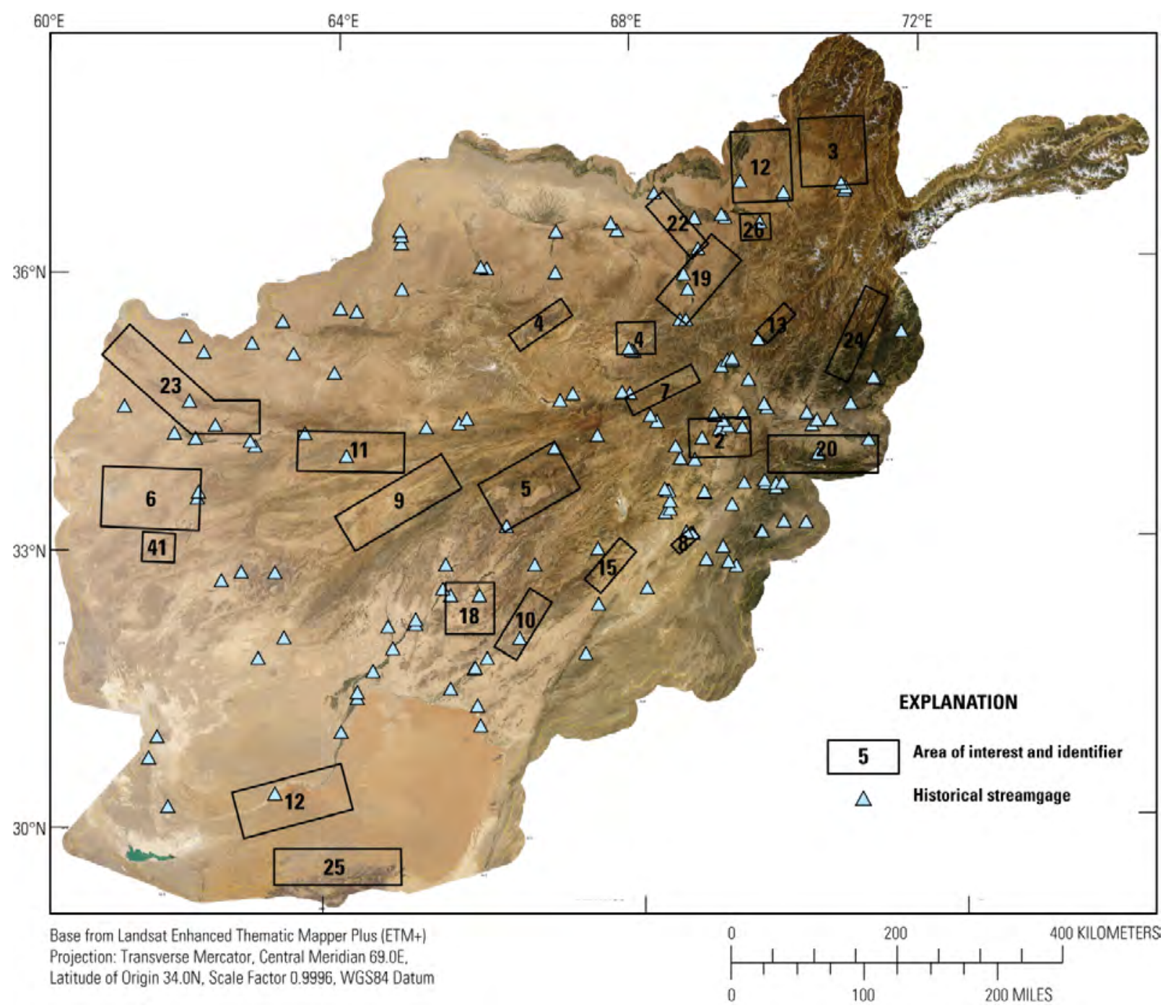

Figure 1. Historical streamgage locations and mineral areas of interest in Afghanistan.

Mineral areas of interest (fig. 1) identified by the U.S. Geological Survey (USGS) and the Afghanistan Geological Survey (AGS) (Peters and others, 2007) were the subject of additional study as part of a cooperative investigation of the USGS and the U.S. Task Force for Business and Stability Operations (TFBSO) from 2009 to 2011 (Peters and others, 2011). As part of this investigation, the USGS conducted field investigations and preliminary hydrologic site assessments, including estimation of surface- and groundwater resources at the mineral areas of interest. This report documents a technique for estimating streamflow statistics, primarily low to average flows, at ungaged sites in these areas. The technique, a drainage-area ratio equation with empirical factors derived by regression, was applied in a parallel investigation which provides estimates of streamflow statistics for selected mineral areas of interest in Afghanistan (Peters and others, 2011). Streamflow statistics generated with this technique, together with geologic data and other information, can be used by resource managers in Afghanistan to make economic decisions concerning the mineral areas of interest. 


\section{Streamgages Used for Estimation of Streamflow Statistics}

Streamflow measurements in Afghanistan were first made at a few gaged locations in the mid1940s. The number of streamgages increased over the years until the late 1970s, when Afghanistan had a network of approximately 160 sites. Streamflow measurements were discontinued soon after the Soviet invasion of Afghanistan in 1979. In 2005, three historical streamgages were re-established, and currently (2011) much of the historical network is in the process of being re-established by the Afghanistan Ministry of Energy and Water (MEW). No recent streamflow data were available for this study, however, and only data collected prior to 1980 were used in this analysis.

Of the 150 streamgages for which historical streamflow data were available, several criteria limited the number of eligible streamgages used in development of the technique for estimating streamflow statistics to 97 . The first criterion required that streamflow at the gage be only minimally impacted by human activities. This criterion eliminated several streamgages that were located downstream from reservoirs, as well as many streamgages that were located within or downstream from areas of extensive irrigation. Because irrigation, which is common in Afghanistan, may complicate streamflow statistics, a criterion was established that basins in which greater than 10 percent of the area was classified as irrigated land (Afghanistan Information Management Service, 1997) were eliminated from the analyses. Additionally, streamgages whose basins are in the southwestern plains regions were eliminated from analysis because runoff characteristics in these basins are typically dominated by losses to groundwater and can be significantly different from the characteristics of streamflow in the mountainous basins that cover much of Afghanistan.

Another criterion was related to the minimum number of years of streamflow data available at a streamgage. For estimating flow-duration statistics, monthly and annual means, and monthly minimums, streamgages with as few as 4 complete water years of data collection were used in the analyses. The minimum number of years of available data used for streamflow estimation studies is typically 10 , but the number of sites used in this analysis would have been severely limited had that criterion been used.

The number of streamgages used in the final analyses was further reduced because streamgages having streamflow values equal to zero for the selected flow characteristics were removed from the analyses. This criterion was necessary because of the strong relation that exists between basin characteristics and the logarithm of streamflow values, and the fact that the logarithm of zero does not exist. After all these criteria were met, the number of streamgages used in the analyses was (1) 89 streamgages for flow duration, (2) 93 streamgages for mean monthly streamflow and mean annual streamflow, and (3) 83 streamgages for minimum mean monthly streamflow. Of the 93 streamgages, 21 had more than 15 years of record, 32 had 10 to 15 years of record, and 40 had less than 10 years of record. The streamgages used in the analyses are listed in table 1.

The streamflow statistics that were used in this analysis can be found in Williams-Sether (2008), Olson and Williams-Sether (2010), and Vining (2010); the exception is 7-day low-flow annual series for each streamgage, which were computed from the daily mean streamflows available in the USGS National Water Information System database at http://waterdata.usgs.gov. 
Table 1. Streamgages used for estimation of streamflow statistics in mineral areas of interest in Afghanistan. [USGS, U.S. Geological Survey; x, used for estimation; --, no data]

\begin{tabular}{|c|c|c|c|c|c|}
\hline \multirow[b]{2}{*}{$\begin{array}{l}\text { USGS streamgage } \\
\text { identification number }\end{array}$} & \multirow[b]{2}{*}{ Streamgage name } & \multicolumn{4}{|c|}{$\begin{array}{l}\text { Streamgage data used in the development of the } \\
\text { equation for estimating: }\end{array}$} \\
\hline & & $\begin{array}{c}\text { Mean } \\
\text { monthly and } \\
\text { annual } \\
\text { streamflow }\end{array}$ & $\begin{array}{l}\text { Minimum } \\
\text { monthly } \\
\text { streamflow }\end{array}$ & $\begin{array}{l}\text { Flow } \\
\text { duration }\end{array}$ & $\begin{array}{l}\text { Annual } \\
\text { minimum } \\
7 \text {-day } \\
\text { streamflow } \\
\text { statistics }\end{array}$ \\
\hline 315700066020000 & Arghandab River above Arghandab Reservoir & $\mathrm{x}$ & $\mathrm{x}$ & $\mathrm{x}$ & $\mathrm{x}$ \\
\hline 321000066270000 & Arghandab River at Mizan & $\mathrm{x}$ & $\mathrm{x}$ & $\mathrm{x}$ & -- \\
\hline 323800065340000 & Tirin River at Anarjuy & $\mathrm{x}$ & $\mathrm{x}$ & $\mathrm{x}$ & $\mathrm{x}$ \\
\hline 323800065560000 & Tirin River at Tirin & $\mathrm{x}$ & $\mathrm{x}$ & $\mathrm{x}$ & $\mathrm{x}$ \\
\hline 324200065280000 & Helmand River at Dehraut & $\mathrm{x}$ & $\mathrm{x}$ & $\mathrm{x}$ & $\mathrm{x}$ \\
\hline 325100062520000 & Farah River near Petch Tangi & $\mathrm{x}$ & -- & $\mathrm{x}$ & -- \\
\hline 325100063180000 & Malmand River near Shawalat & $\mathrm{x}$ & $\mathrm{x}$ & $\mathrm{x}$ & $\mathrm{x}$ \\
\hline 325500069150000 & Urgun River at Pirkoti & $\mathrm{x}$ & -- & $\mathrm{x}$ & -- \\
\hline 325800065300000 & Kaj River at Yakhdan & $\mathrm{x}$ & $\mathrm{x}$ & $\mathrm{x}$ & -- \\
\hline 325800066390000 & Tirin River at Urosgan & $\mathrm{x}$ & $\mathrm{x}$ & $\mathrm{x}$ & $\mathrm{x}$ \\
\hline 325800069090000 & Dahane Legad River near Urgun & $\mathrm{x}$ & $\mathrm{x}$ & $\mathrm{x}$ & -- \\
\hline 330000068520000 & Park River near Park Dasht & $\mathrm{x}$ & $\mathrm{x}$ & $\mathrm{x}$ & -- \\
\hline 330800067280000 & Arghandab River at Sang-i-Masha & $\mathrm{x}$ & $\mathrm{x}$ & $\mathrm{x}$ & $\mathrm{x}$ \\
\hline 331700069360000 & Spera River near Spera & $\mathrm{x}$ & $\mathrm{x}$ & $\mathrm{x}$ & $\mathrm{x}$ \\
\hline 332200070100000 & Shumal River at Tora Tigha & $\mathrm{x}$ & $\mathrm{x}$ & $\mathrm{x}$ & $\mathrm{x}$ \\
\hline 332300066170000 & Helmand River at Gizab & $\mathrm{x}$ & $\mathrm{x}$ & $\mathrm{x}$ & -- \\
\hline 332300069530000 & Matum River at Matum & $\mathrm{x}$ & $\mathrm{x}$ & $\mathrm{x}$ & $\mathrm{x}$ \\
\hline 333800062160000 & Adraskan River at Adraskan & $\mathrm{x}$ & $\mathrm{x}$ & $\mathrm{x}$ & $\mathrm{x}$ \\
\hline 334200062170000 & Rud-i-Gaz River near Adraskan & $\mathrm{x}$ & -- & $\mathrm{x}$ & -- \\
\hline 334300068520000 & Charkh River at Kharwar Dam Inflow & $\mathrm{x}$ & $\mathrm{x}$ & $\mathrm{x}$ & -- \\
\hline 334500069480000 & Gaber River near Chamkani & $\mathrm{x}$ & -- & $\mathrm{x}$ & -- \\
\hline 334600068210000 & Barikab River above Seraj Reservoir & $\mathrm{x}$ & -- & $\mathrm{x}$ & -- \\
\hline 334800069400000 & Khurram River at Doda & $\mathrm{x}$ & $\mathrm{x}$ & $\mathrm{x}$ & -- \\
\hline 334800069480000 & Khurram River at Chamkani & $\mathrm{x}$ & $\mathrm{x}$ & $\mathrm{x}$ & $\mathrm{x}$ \\
\hline 334800069530000 & Khurram River at Pul-i-Bangakh & $\mathrm{x}$ & -- & $\mathrm{x}$ & -- \\
\hline 334900069230000 & Jilga River near Mechalghu & $\mathrm{x}$ & $\mathrm{x}$ & $\mathrm{x}$ & $\mathrm{x}$ \\
\hline 335000069390000 & Khurram River at Ahmadkhel & $\mathrm{x}$ & $\mathrm{x}$ & $\mathrm{x}$ & -- \\
\hline 340500068450000 & Logar River at Shekhabad & $\mathrm{x}$ & $\mathrm{x}$ & $\mathrm{x}$ & $\mathrm{x}$ \\
\hline 340600068340000 & Logar River above Band-i-Chak Wardhak & $\mathrm{x}$ & $\mathrm{x}$ & $\mathrm{x}$ & -- \\
\hline 340800064120000 & Kowgan River at Tangi Azu & $\mathrm{x}$ & $\mathrm{x}$ & $\mathrm{x}$ & $\mathrm{x}$ \\
\hline 341300063000000 & Kowgan River at Langar & $\mathrm{x}$ & $\mathrm{x}$ & $\mathrm{x}$ & $\mathrm{x}$ \\
\hline 341400066550000 & Punjab River at Waras & $\mathrm{x}$ & $\mathrm{x}$ & $\mathrm{x}$ & $\mathrm{x}$ \\
\hline 341400068300000 & Logar River at Kajab & $\mathrm{x}$ & $\mathrm{x}$ & $\mathrm{x}$ & $\mathrm{x}$ \\
\hline 341400071020000 & Kabul River at Dakah & $\mathrm{x}$ & $\mathrm{x}$ & $\mathrm{x}$ & $\mathrm{x}$ \\
\hline 341600062560000 & Hari Rud River at Robat-i-Akhond & $\mathrm{x}$ & $\mathrm{x}$ & $\mathrm{x}$ & $\mathrm{x}$ \\
\hline
\end{tabular}


Table 1. Streamgages used for estimation of streamflow statistics in mineral areas of interest in Afghanistan. [USGS, U.S. Geological Survey; x, used for estimation; --, no data]

\begin{tabular}{|c|c|c|c|c|c|}
\hline \multirow[b]{2}{*}{$\begin{array}{l}\text { USGS streamgage } \\
\text { identification number }\end{array}$} & \multirow[b]{2}{*}{ Streamgage name } & \multicolumn{4}{|c|}{$\begin{array}{l}\text { Streamgage data used in the development of the } \\
\text { equation for estimating: }\end{array}$} \\
\hline & & $\begin{array}{c}\text { Mean } \\
\text { monthly and } \\
\text { annual } \\
\text { streamflow }\end{array}$ & $\begin{array}{l}\text { Minimum } \\
\text { monthly } \\
\text { streamflow }\end{array}$ & $\begin{array}{l}\text { Flow } \\
\text { duration }\end{array}$ & $\begin{array}{l}\text { Annual } \\
\text { minimum } \\
7 \text {-day } \\
\text { streamflow } \\
\text { statistics }\end{array}$ \\
\hline 342100063390000 & Hari Rud at Tagaw Ghaza & $\mathrm{x}$ & $\mathrm{x}$ & $\mathrm{x}$ & $\mathrm{x}$ \\
\hline 342100067290000 & Markhana River at Dahane Rishqa & $\mathrm{x}$ & $\mathrm{x}$ & $\mathrm{x}$ & $\mathrm{x}$ \\
\hline 342400069050000 & Kabul River at Tangi Saidan & $\mathrm{x}$ & $\mathrm{x}$ & $\mathrm{x}$ & $\mathrm{x}$ \\
\hline 342500069230000 & Chakari River at Band-i-Amir Ghazi & $\mathrm{x}$ & $\mathrm{x}$ & $\mathrm{x}$ & $\mathrm{x}$ \\
\hline 342500070180000 & Surkhrud River near Sultanpur & $\mathrm{x}$ & -- & -- & -- \\
\hline 342600062280000 & Karukh River near Herat & $\mathrm{x}$ & $\mathrm{x}$ & $\mathrm{x}$ & -- \\
\hline 342600069120000 & Logar River at Sang-i-Naweshta & $\mathrm{x}$ & $\mathrm{x}$ & $\mathrm{x}$ & $\mathrm{x}$ \\
\hline 342800070220000 & Kabul River near Daronta & $\mathrm{x}$ & $\mathrm{x}$ & $\mathrm{x}$ & -- \\
\hline 342800070330000 & Konar River at Pul-i-Kama & $\mathrm{x}$ & $\mathrm{x}$ & $\mathrm{x}$ & $\mathrm{x}$ \\
\hline 343000068160000 & Helmand River at Gardandewal & $\mathrm{x}$ & $\mathrm{x}$ & $\mathrm{x}$ & $\mathrm{x}$ \\
\hline 343100065150000 & Hari Rud River at Chekhcheran & $\mathrm{x}$ & $\mathrm{x}$ & $\mathrm{x}$ & $\mathrm{x}$ \\
\hline 343300065460000 & Hari Rud River at Daulatyar & $\mathrm{x}$ & $\mathrm{x}$ & $\mathrm{x}$ & $\mathrm{x}$ \\
\hline 343300070140000 & Laghman River at Pul-i-Qarghai & $\mathrm{x}$ & $\mathrm{x}$ & $\mathrm{x}$ & $\mathrm{x}$ \\
\hline 343400068110000 & Syahang River near Gardandewal & $\mathrm{x}$ & $\mathrm{x}$ & $\mathrm{x}$ & $\mathrm{x}$ \\
\hline 343400069240000 & Kabul River at Tang-i-Gharu & $\mathrm{x}$ & $\mathrm{x}$ & $\mathrm{x}$ & $\mathrm{x}$ \\
\hline 343700069430000 & Kabul River at Naghlu & $\mathrm{x}$ & $\mathrm{x}$ & $\mathrm{x}$ & $\mathrm{x}$ \\
\hline 343800070490000 & Konar River near Konari & $\mathrm{x}$ & $\mathrm{x}$ & $\mathrm{x}$ & $\mathrm{x}$ \\
\hline 344000069410000 & Tagab River at Tagab & $\mathrm{x}$ & $\mathrm{x}$ & $\mathrm{x}$ & -- \\
\hline 344500067000000 & Balkh River near Nayak & $\mathrm{x}$ & $\mathrm{x}$ & $\mathrm{x}$ & $\mathrm{x}$ \\
\hline 345000067490000 & Bamyan River at Bamyan & $\mathrm{x}$ & $\mathrm{x}$ & $\mathrm{x}$ & -- \\
\hline 345300071100000 & Konar River near Asmar & $\mathrm{x}$ & $\mathrm{x}$ & $\mathrm{x}$ & $\mathrm{x}$ \\
\hline 345400071080000 & Pech River at Chaghasarai & $\mathrm{x}$ & $\mathrm{x}$ & $\mathrm{x}$ & $\mathrm{x}$ \\
\hline 350200064010000 & Murghab River at Qala-i-niazkhan & $\mathrm{x}$ & $\mathrm{x}$ & $\mathrm{x}$ & $\mathrm{x}$ \\
\hline 350500069080000 & Ghorband River at Pul-i-Ashawa & $\mathrm{x}$ & $\mathrm{x}$ & $\mathrm{x}$ & $\mathrm{x}$ \\
\hline 350900069130000 & Salang River at Bagh-i-Lala & $\mathrm{x}$ & $\mathrm{x}$ & $\mathrm{x}$ & $\mathrm{x}$ \\
\hline 350900069170000 & Shatul River at Gulbahar & $\mathrm{x}$ & $\mathrm{x}$ & $\mathrm{x}$ & $\mathrm{x}$ \\
\hline 351000069170000 & Panjsher River at Gulbahar & $\mathrm{x}$ & $\mathrm{x}$ & $\mathrm{x}$ & $\mathrm{x}$ \\
\hline 351300062170000 & Kushk River at Chil Dukhtaran & $\mathrm{x}$ & $\mathrm{x}$ & $\mathrm{x}$ & -- \\
\hline 351400063280000 & Bum River at Luka-i-Surkh & $\mathrm{x}$ & $\mathrm{x}$ & $\mathrm{x}$ & -- \\
\hline 351600067590000 & Bamyan River at Doab & $\mathrm{x}$ & $\mathrm{x}$ & $\mathrm{x}$ & $\mathrm{x}$ \\
\hline 351800067550000 & Kunduz River at Dasht-i-Safed & $\mathrm{x}$ & $\mathrm{x}$ & $\mathrm{x}$ & -- \\
\hline 352000062550000 & Kashan River at Babulai & $\mathrm{x}$ & -- & -- & -- \\
\hline 352200069380000 & Panjsher River at Omarz & $\mathrm{x}$ & $\mathrm{x}$ & $\mathrm{x}$ & $\mathrm{x}$ \\
\hline 353500063190000 & Murghab River at Bala Murghab & $\mathrm{x}$ & $\mathrm{x}$ & $\mathrm{x}$ & $\mathrm{x}$ \\
\hline 353600068360000 & Kunduz River at Pul-i-Konda Sang & $\mathrm{x}$ & $\mathrm{x}$ & $\mathrm{x}$ & $\mathrm{x}$ \\
\hline
\end{tabular}


Table 1. Streamgages used for estimation of streamflow statistics in mineral areas of interest in Afghanistan. [USGS, U.S. Geological Survey; x, used for estimation; --, no data]

\begin{tabular}{|c|c|c|c|c|c|}
\hline \multirow[b]{2}{*}{$\begin{array}{l}\text { USGS streamgage } \\
\text { identification number }\end{array}$} & \multirow[b]{2}{*}{ Streamgage name } & \multicolumn{4}{|c|}{$\begin{array}{l}\text { Streamgage data used in the development of the } \\
\text { equation for estimating: }\end{array}$} \\
\hline & & $\begin{array}{c}\text { Mean } \\
\text { monthly and } \\
\text { annual } \\
\text { streamflow }\end{array}$ & $\begin{array}{l}\text { Minimum } \\
\text { monthly } \\
\text { streamflow }\end{array}$ & $\begin{array}{l}\text { Flow } \\
\text { duration }\end{array}$ & $\begin{array}{c}\text { Annual } \\
\text { minimum } \\
\text { 7-day } \\
\text { streamflow } \\
\text { statistics }\end{array}$ \\
\hline 353600068410000 & Andarab River at Doshi & $\mathrm{x}$ & $\mathrm{x}$ & $\mathrm{x}$ & $\mathrm{x}$ \\
\hline 355600068430000 & Kunduz River at Pul-i-Khumri & $\mathrm{x}$ & $\mathrm{x}$ & $\mathrm{x}$ & $\mathrm{x}$ \\
\hline 355700064540000 & Shirin Tagab River at Khisht Pul & $\mathrm{x}$ & $\mathrm{x}$ & $\mathrm{x}$ & $\mathrm{x}$ \\
\hline 360600068400000 & Kunduz River at Baghlan & $\mathrm{x}$ & $\mathrm{x}$ & $\mathrm{x}$ & $\mathrm{x}$ \\
\hline 360800066570000 & Suf River near Kishandeh & $\mathrm{x}$ & -- & -- & -- \\
\hline 361100066020000 & Shorab River near Sare Pul & $\mathrm{x}$ & $\mathrm{x}$ & $\mathrm{x}$ & $\mathrm{x}$ \\
\hline 361200065570000 & Sare Pul River at Asiabad & $\mathrm{x}$ & $\mathrm{x}$ & $\mathrm{x}$ & $\mathrm{x}$ \\
\hline 362200068520000 & Kunduz River at Gerdab & $\mathrm{x}$ & $\mathrm{x}$ & $\mathrm{x}$ & $\mathrm{x}$ \\
\hline 362700064530000 & Shirin Tagab River at Daulatabad & $\mathrm{x}$ & $\mathrm{x}$ & $\mathrm{x}$ & -- \\
\hline 363200064530000 & Maimana River near Pata Baba & $\mathrm{x}$ & -- & -- & -- \\
\hline 363500064520000 & Shirin Tagab River at Pata Baba & $\mathrm{x}$ & $\mathrm{x}$ & $\mathrm{x}$ & $\mathrm{x}$ \\
\hline 363500066580000 & Balkh River at Rabat-i-Bala & $\mathrm{x}$ & $\mathrm{x}$ & $\mathrm{x}$ & $\mathrm{x}$ \\
\hline 363500067470000 & Khulm River at Sayad & $\mathrm{x}$ & $\mathrm{x}$ & $\mathrm{x}$ & $\mathrm{x}$ \\
\hline 363800069430000 & Farkhar River near Taloqan & $\mathrm{x}$ & $\mathrm{x}$ & $\mathrm{x}$ & $\mathrm{x}$ \\
\hline 364000067420000 & Khulm River at Tangi Tashqurghan & $\mathrm{x}$ & $\mathrm{x}$ & $\mathrm{x}$ & $\mathrm{x}$ \\
\hline 364200069150000 & Bangi River at Pul-i-Bangi & $\mathrm{x}$ & $\mathrm{x}$ & $\mathrm{x}$ & $\mathrm{x}$ \\
\hline 364400069120000 & Taloqan River at Pul-i-Chugha & $\mathrm{x}$ & $\mathrm{x}$ & $\mathrm{x}$ & $\mathrm{x}$ \\
\hline 365500070030000 & Keshem River near Keshem & $\mathrm{x}$ & $\mathrm{x}$ & $\mathrm{x}$ & $\mathrm{x}$ \\
\hline 365600070520000 & Kokcha River near Jurm & $\mathrm{x}$ & $\mathrm{x}$ & $\mathrm{x}$ & $\mathrm{x}$ \\
\hline 365700070030000 & Kokcha River near Keshem & $\mathrm{x}$ & $\mathrm{x}$ & $\mathrm{x}$ & $\mathrm{x}$ \\
\hline 365800070540000 & Warduj near Baharak & $\mathrm{x}$ & $\mathrm{x}$ & $\mathrm{x}$ & $\mathrm{x}$ \\
\hline 370100070500000 & Warduj River at Shashpul & $\mathrm{x}$ & $\mathrm{x}$ & $\mathrm{x}$ & $\mathrm{x}$ \\
\hline 370500069280000 & Kokcha River at Khojaghar & $\mathrm{x}$ & $\mathrm{x}$ & $\mathrm{x}$ & $\mathrm{x}$ \\
\hline
\end{tabular}

\section{Basin Characteristics for Gaged and Ungaged Locations}

Drainage-basin boundaries for the streamgages were determined using a Geographic Information System (GIS) and a digital flow-direction grid derived from a 90-meter digital elevation model of Afghanistan (Chirico and Barrios, 2005). Additional dimensional basin characteristics were computed with ArcHydro software (Environmental Systems Research Institute, Inc., 2008), also using the digital elevation model. Gridded precipitation data published by the International Institute of Applied Systems Analyses (Leemans and Cramer, 1991) were used to determine the precipitation characteristics for each streamgage. The basin characteristics for the streamgages used in the study are shown in appendix 1 (at end of report) and may differ from characteristics reported by other studies. 


\section{Estimation of Streamflow Statistics at Ungaged Locations}

Methods for estimating streamflow statistics at ungaged stream sites in mineral areas of interest were developed using a drainage-area-ratio technique, with empirical factors derived by using selected gages from the historical network, and individual historical gages. Although more detailed regression analyses that included regional, topographic, and estimated climatic variables were also examined during this study, the standard errors of regression and resulting flow statistics indicated that such an analysis could not be justified without additional, higher quality input data.

For an ungaged site, streamflow statistics can be generated using nearby historical gages where available or, if no gage is near the ungaged site, a historical gage in a similar setting. One or more historical gages are present upstream or downstream from several of the mineral areas of interest. In this case, logarithmic interpretations, based on ratios of gaged to ungaged drainage areas, can be used to estimate streamflow statistics at an ungaged site. Estimates of streamflow statistics generated using the methods discussed in this report, and data from various historical gages, were used in a parallel investigation assessing mineral areas of interest in Afghanistan (Peters and others, 2011). Because the generated streamflow statistics use historical data for basins that may differ in size and hydrologic setting from those of the ungaged site, no information is available with which to assign a confidence to the streamflow statistics at the ungaged site.

\section{Equations for Estimation of Streamflow Statistics at Ungaged Locations}

The drainage-area-ratio technique is a useful method for estimating streamflow statistics when one or more streamgages are present in the vicinity of, or in an area with characteristics similar to those of, the area containing the ungaged location of interest. Typically, the drainage area of the ungaged point of interest is limited to being within a certain percentage of the drainage area of the streamgage. Published limits for this technique vary, but the rule of thumb most commonly used is to limit the size of the drainage area of the ungaged point of interest to \pm 50 percent of the size of the drainage area of the streamgage.

The following equation is used:

$$
Q_{u}=Q_{g}\left(\frac{A_{u}}{A_{g}}\right),
$$

where $A_{u}$ and $A_{g}$ are the drainage areas of the ungaged and gaged locations, respectively, and $Q_{u}$ and $Q_{g}$ are the streamflows at the ungaged and gaged locations, respectively. The technique relies on the relation commonly found between drainage area and streamflow. This relation is typically more linear when logarithmic units are used (fig. 2). The mean relation between drainage area and streamflow in logarithmic units is determined by regression for each streamflow statistic. These logarithmic relations are then used in the equation

$$
Q_{u}=Q_{g}\left(\frac{A_{u}}{A_{g}}\right)^{x},
$$

where $x$ is the slope of the relation between drainage area and streamflow in logarithmic units determined by regression. The exponent, $x$, can be found in table 2 for each of the streamflow statistics. 
Table 2. Suggested drainage-area-ratio exponents for estimation of streamflow statistics in mineral areas of interest in Afghanistan.

\begin{tabular}{lc}
\hline \multicolumn{1}{c}{ Streamflow (discharge) statistic } & Drainage-area-ratio exponent \\
\hline 7-day low flow with 10-year recurrence interval, 7Q10 & 1.14 \\
7-day low flow with 2-year recurrence interval, 7Q2 & 1.03 \\
90-percent flow-duration discharge, $\mathrm{D}_{90}$ & 1.25 \\
80-percent flow-duration discharge, $\mathrm{D}_{80}$ & 1.18 \\
October mean monthly discharge, $\mathrm{OCT}_{\text {mean }}$ & 1.10 \\
November mean monthly discharge, $\mathrm{NOV}_{\text {mean }}$ & 1.09 \\
December mean monthly discharge, $\mathrm{DEC}_{\text {mean }}$ & 1.08 \\
January mean monthly discharge, $\mathrm{JAN}_{\text {mean }}$ & 1.06 \\
February mean monthly discharge, $\mathrm{FEB}_{\text {mean }}$ & 1.00 \\
March mean monthly discharge, $\mathrm{MAR}_{\text {mean }}$ & 0.92 \\
April mean monthly discharge, $\mathrm{APR}_{\text {mean }}$ & 0.90 \\
May mean monthly discharge, $\mathrm{MAY}_{\text {mean }}$ & 1.05 \\
June mean monthly discharge, $\mathrm{JUN}_{\text {mean }}$ & 1.18 \\
July mean monthly discharge, $\mathrm{JUL}_{\text {mean }}$ & 1.08 \\
August mean monthly discharge, $\mathrm{AUG}_{\text {mean }}$ & 1.06 \\
September mean monthly discharge, $\mathrm{SEP}_{\text {mean }}$ & 1.09 \\
Mean annual discharge, ANN & 1.04 \\
Octoaner minimum monthly discharge, $\mathrm{OCT}_{\min }$ & 1.20 \\
November minimum monthly discharge, $\mathrm{NOV}_{\text {min }}$ & 1.19 \\
December minimum monthly discharge, $\mathrm{DEC}_{\min }$ & 1.18 \\
January minimum monthly discharge, $\mathrm{JAN}_{\min }$ & 1.21 \\
February minimum monthly discharge, $\mathrm{FEB}_{\min }$ & 1.17 \\
March minimum monthly discharge, $\mathrm{MAR}_{\min }$ & 1.04 \\
April minimum monthly discharge, $\mathrm{APR}_{\min }$ & 1.03 \\
May minimum monthly discharge, $\mathrm{MAY}_{\min }$ & 1.17 \\
June minimum monthly discharge, $\mathrm{JUN}_{\min }$ & 1.30 \\
July minimum monthly discharge, $\mathrm{JUL}_{\min }$ & 1.25 \\
August minimum monthly discharge, $\mathrm{AUG}_{\min }$ & 1.29 \\
September minimum monthly discharge, $\mathrm{SEP}_{\text {min }}$ & 1.27 \\
\hline
\end{tabular}




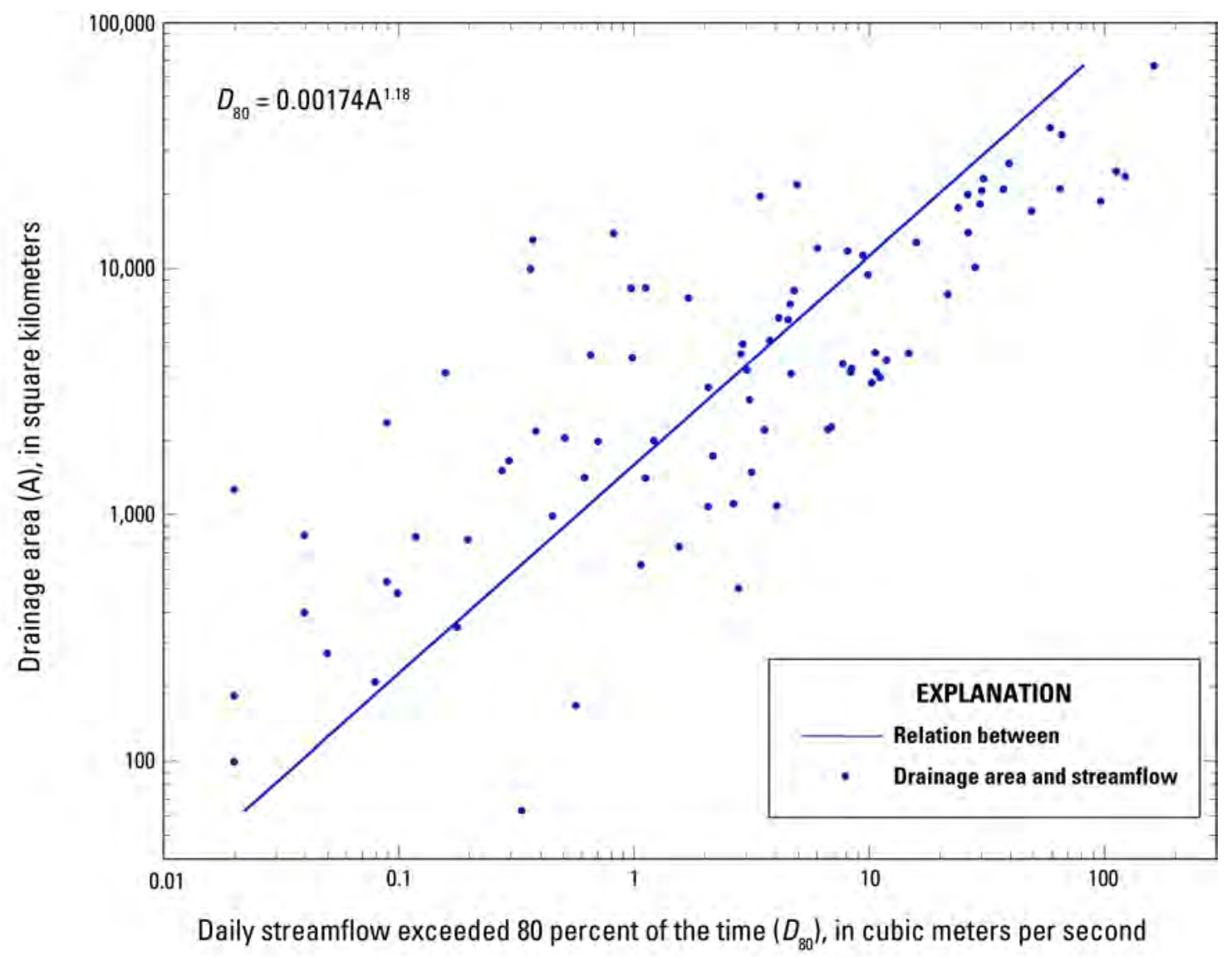

Figure 2. Drainage area verses daily streamflow exceeded 80 percent of the time (D80) for historical streamgages used in this investigation of mineral areas of interest in Afghanistan. 


\section{Application of Streamflow Statistics at Ungaged Locations}

Streamflow statistics for an ungaged location can be estimated using equation 2 to provide some probable estimates of flow in a mineral area of interest. Ideally, the historical streamgage selected for use with equation 2 would be on the same stream as the ungaged location, with no intervening regulation. In practice, the streamgage used to calculate a streamflow statistic at an ungaged site may not be on the same stream and may not have the same size drainage area. The best choice for a gage would be a nearby gage with similar basin characteristics or, if there are no nearby gages, a gage in a similar region of the country (north, south, east, or west) with similar geohydrologic characteristics. For example, to estimate streamflow statistics at an ungaged stream in the mineral area of interest number 6 (fig. 1), the Dusar-Shaida copper and tin mineral area of interest (Peters and others, 2007), one of the two historical streamgages at the eastern boundary of the area of interest, the Adraskan River at Adraskan or the Rud-i-Gaz River near Adraskan (table 1, appendix 1), would likely be the most representative historical gage for use with this method because of its proximity to the estimation point. Using a historical mean annual streamflow of $6.53 \mathrm{~m}^{3} / \mathrm{s}$ for the Adraskan River, a 1,950- $\mathrm{km}^{2}$ drainage area, and an exponent of 1.04 for mean annual discharge (table 2) with equation 2, the mean annual flow for a stream with a $2,900-\mathrm{km}^{2}$ drainage area in the Dusar-Shaida area of interest is estimated to be about $9.9 \mathrm{~m}^{3} / \mathrm{s}$. Statistical summaries of streamflow data for all available historical gages in Afghanistan can be accessed at http://afghanistan.cr.usgs.gov/water.php.

\section{Limitations of Streamflow Statistics at Ungaged Locations}

The analyses presented in this report were based on streamflow records that, for some streamgages, were shorter than those typically used in such analyses. It was necessary to include gages with short periods of record (less than 10 years) in the analyses in order to include characteristics of streamflow in all areas of the country. In addition, the periods of record of the gages used in the analyses were not necessarily concurrent. Moreover, most of the streamflow data that were used in this study were collected in the 1960s and 1970s; it is not known whether this time period is representative of the long-term hydrology of the region, nor how streamflow may have been affected by climatic variations over time. Any climatic changes that may have occurred since 1980 may further limit the accuracy of the estimated streamflow statistics. For these reasons, streamflow statistics calculated using the equations presented in this report are considered preliminary and should be used with an understanding that they may not accurately represent the streamflow in the basin of interest. Improved streamflow statistics can be developed when additional streamflow and climatic data become available.

This technique for estimating streamflow statistics is applicable only to basins that are hydrologically similar to those used in the development of the drainage-area-ratio relations. Therefore, the technique may not be suited for use with regulated streams in basins that consist of more than 10 percent irrigated land. Furthermore, the equations can only be reasonably used to estimate streamflow statistics for sites whose basins have characteristics that are within the range of basin characteristics used in the development of the equations. The ranges of basin characteristics used in the analysis are shown in appendix 1. If the characteristics of basins of ungaged sites are outside these ranges, the results are considered extrapolations. 


\section{Summary}

This report documents a technique for estimating streamflow statistics at ungaged sites in mineral areas of interest in Afghanistan. The technique produces equations that can be used to estimate streamflow statistics at an ungaged site using a ratio of its drainage area to the drainage area of a hydrologically similar site with known streamflow statistics determined from streamflow data collected at gaged locations in Afghanistan through 1980. Equations incorporating the drainage-area ratio were developed for estimating the (1) 7-day low flow with a 10-year recurrence interval, (2) 7-day low flow with a 2-year recurrence interval, (3) daily mean streamflow exceeded 90 percent of the time, (4) daily mean streamflow exceeded 80 percent of the time, (5) mean monthly streamflow for each month of the year, (6) mean annual streamflow, and (7) minimum monthly streamflow for each month of the year. Improved streamflow statistics could be developed given longer streamflow records and additional climatic data that currently (2011) are unavailable.

\section{References Cited}

Afghanistan Information Management Service, 1997, Irrigated areas: Afghanistan Information Management Service, Afghanistan Shape Files, scale 1:250,000, accessed October 15, 2010, at http://www.aims.org.af/ssroots.aspx?seckeyt=295.

Chirico, P., and Barrios, B., 2005, Void filled SRTM digital elevation model of Afghanistan: U.S. Geological Survey Data Series DS-0130, DVD, accessed June 10, 2010, at http://pubs.er.usgs.gov/usgspubs/ds/ds130.

Environmental Systems Research Institute, Inc., 2008, GIS for water resources, accessed June 10, 2010, at http://www.esri.com/industries/water_resources/index.html/.

Leemans, Rik, and Cramer, W.P., 1991, The IIASA database for mean monthly values of temperature, precipitation and cloudiness on a global terrestrial grid: International Institute of Applied Systems Analyses Research Report RR-91-18, 61 p.

Olson, S.A., and Williams-Sether, T., 2010, Streamflow characteristics in Northern Afghanistan and selected locations: U.S. Geological Survey Data Series 529, 512 p., accessed October 15, 2010, at http://pubs.usgs.gov/ds/529/.

Peters, S.G., Ludington, S.D., Orris, G.J., Sutphin, D.M., Bliss, J.D., and Rytuba, J.J., 2007, Preliminary non-fuel mineral assessment of Afghanistan: U.S. Geological Survey Open-File Report 2007-1214, p. 810.

Peters, S.G., King, T.V.V., Mack, T.J., Chornack, M.P., and others, 2011, Summaries of important areas for mineral investment and production opportunities of nonfuel minerals in Afghanistan: U.S. Geological Survey Open-File Report 2011-1204, at http://pubs.usgs.gov/of/2011/1204/.

Vining, K.C., 2010, Streamflow characteristics in southeastern Afghanistan: U.S. Geological Survey Data Series 508, 104 p., accessed October 15, 2010, at http://pubs.usgs.gov/ds/508/.

Williams-Sether, Tara, 2008, Streamflow characteristics of streams in the Helmand Basin, Afghanistan: U.S. Geological Survey Data Series 333, 341 p., accessed October 15, 2010, at http://pubs.usgs.gov/ds/333/. 


\section{Appendix 1. Basin Characteristics for Streamgages Used for Estimation of Streamflow at Ungaged Locations in Mineral Areas of Interest in Afghanistan}


Appendix 1. Basin characteristics for streamgages used for estimation of streamflow at ungaged locations in mineral areas of interest in Afghanistan.

[USGS, U.S. Geological Survey; $\mathrm{km}^{2}$, square kilometers; m, meters; mm, millimeters]

\begin{tabular}{|c|c|c|c|c|c|c|c|c|c|c|}
\hline \multirow{2}{*}{$\begin{array}{l}\text { USGS streamgage } \\
\text { identification } \\
\text { number }\end{array}$} & \multirow{2}{*}{ Streamgage name } & \multirow{2}{*}{$\begin{array}{l}\text { Drainage } \\
\text { area }^{1} \\
\left(\mathrm{~km}^{2}\right)\end{array}$} & \multirow{2}{*}{$\begin{array}{l}\text { Mean } \\
\text { basin } \\
\text { slope } \\
\text { (percent) }\end{array}$} & \multirow{2}{*}{$\begin{array}{l}\text { Elevation } \\
\text { of basin } \\
\text { centroid } \\
\quad(\mathrm{m})\end{array}$} & \multirow{2}{*}{$\begin{array}{l}\text { Percent- } \\
\text { age of } \\
\text { basin } \\
\text { above } \\
3,000 \mathrm{~m}\end{array}$} & \multicolumn{4}{|c|}{$\begin{array}{l}\text { Basinwide mean of monthly precipitation }{ }^{2} \\
(\mathrm{~mm})\end{array}$} & \multirow{2}{*}{$\begin{array}{l}\text { Percentage } \\
\text { of basin } \\
\text { consisting of } \\
\text { irrigated land }\end{array}$} \\
\hline & & & & & & $\begin{array}{l}\text { Octo- } \\
\text { ber }\end{array}$ & $\begin{array}{l}\text { Novem- } \\
\text { ber }\end{array}$ & $\begin{array}{l}\text { Decem- } \\
\text { ber }\end{array}$ & January & \\
\hline 315700066020000 & $\begin{array}{l}\text { Arghandab River above } \\
\text { Arghandab Reservoir }\end{array}$ & 11,200 & 26.8 & 3,270 & 25.1 & 6.1 & 15.2 & 31.7 & 47.2 & 6.47 \\
\hline 321000066270000 & Arghandab River at Mizan & 9,340 & 27.6 & 2,700 & 29.9 & 6.7 & 16.4 & 32.4 & 47.1 & 6.93 \\
\hline 323800065340000 & Tirin River at Anarjuy & 8,060 & 24.3 & 1,860 & 10.9 & 5.1 & 12.5 & 28.4 & 44.2 & 7.72 \\
\hline 323800065560000 & Tirin River at Tirin & 3,690 & 27.7 & 2,080 & 19.0 & 6.9 & 16.0 & 31.0 & 45.3 & 4.53 \\
\hline 324200065280000 & Helmand River at Dehraut & 37,100 & 33.6 & 3,230 & 32.3 & 10.6 & 21.3 & 33.4 & 43.5 & 3.52 \\
\hline 325100062520000 & Farah River near Petch Tangi & 19,400 & 26.1 & 1,840 & 4.75 & 8.0 & 15.1 & 32.2 & 41.0 & 1.59 \\
\hline 325100063180000 & Malmand River near Shawalat & 1,480 & 27.4 & 1,430 & 4.62 & 3.8 & 10.3 & 24.9 & 34.8 & 0.19 \\
\hline 325500069150000 & Urgun River at Pirkoti & 803 & 14.9 & 2,280 & 1.87 & 7.3 & 17.3 & 33.0 & 47.5 & 6.98 \\
\hline 325800065300000 & Kaj River at Yakhdan & 11,600 & 31.0 & 2,180 & 9.98 & 9.1 & 15.0 & 29.6 & 39.6 & 3.14 \\
\hline 325800066390000 & Tirin River at Urosgan & 1,060 & 30.9 & 2,860 & 36.6 & 9.3 & 22.1 & 35.9 & 48.4 & 4.71 \\
\hline 325800069090000 & $\begin{array}{l}\text { Dahane Legad River near } \\
\text { Urgun }\end{array}$ & 177 & 17.2 & 2,410 & 3.99 & 7.0 & 17.1 & 33.0 & 47.5 & 0.97 \\
\hline 330000068520000 & Park River near Park Dasht & 264 & 14.1 & 2,490 & 2.73 & 4.3 & 12.7 & 27.2 & 40.4 & 4.43 \\
\hline 330800067280000 & $\begin{array}{l}\text { Arghandab River at Sang-i- } \\
\text { Masha }\end{array}$ & 2,170 & 30.6 & 3,210 & 67.0 & 10.7 & 26.5 & 41.5 & 54.6 & 6.50 \\
\hline 331700069360000 & Spera River near Spera & 771 & 32.3 & 2,010 & 7.48 & 10.1 & 19.5 & 35.2 & 51.5 & 1.69 \\
\hline 332200070100000 & Shumal River at Tora Tigha & 4,280 & 23.3 & 1,480 & 3.51 & 11.0 & 17.5 & 31.5 & 45.9 & 8.54 \\
\hline 332300066170000 & Helmand River at Gizab & 20,700 & 34.5 & 2,810 & 50.6 & 12.4 & 27.0 & 37.3 & 46.8 & 3.83 \\
\hline 332300069530000 & Matun River at Matun & 338 & 32.0 & 1,870 & 4.10 & 12.4 & 20.1 & 35.1 & 52.4 & 2.03 \\
\hline 333800062160000 & Adraskan River at Adraskan & 1,950 & 26.1 & 2,390 & 7.56 & 7.3 & 16.3 & 32.8 & 42.8 & 4.46 \\
\hline 334200062170000 & $\begin{array}{l}\text { Rud-i-Gaz River near } \\
\text { Adraskan }\end{array}$ & 2,140 & 19.4 & 2,420 & 0.71 & 7.1 & 16.6 & 32.0 & 42.7 & 1.57 \\
\hline 334300068520000 & $\begin{array}{l}\text { Charkh River at Kharwar Dam } \\
\text { Inflow }\end{array}$ & 519 & 15.4 & 2,470 & 9.30 & 4.5 & 17.1 & 33.3 & 49.2 & 7.26 \\
\hline
\end{tabular}


Appendix 1. Basin characteristics for streamgages used for estimation of streamflow at ungaged locations in mineral areas of interest in Afghanistan.

[USGS, U.S. Geological Survey; $\mathrm{km}^{2}$, square kilometers; m, meters; mm, millimeters]

\begin{tabular}{|c|c|c|c|c|c|c|c|c|c|c|}
\hline \multirow{2}{*}{$\begin{array}{l}\text { USGS streamgage } \\
\text { identification } \\
\text { number }\end{array}$} & \multirow[b]{2}{*}{ Streamgage name } & \multirow{2}{*}{$\begin{array}{c}\text { Drainage } \\
\text { area }{ }^{1} \\
\left(\mathrm{~km}^{2}\right)\end{array}$} & \multirow{2}{*}{$\begin{array}{c}\text { Mean } \\
\text { basin } \\
\text { slope } \\
\text { (percent) }\end{array}$} & \multirow{2}{*}{$\begin{array}{l}\text { Elevation } \\
\text { of basin } \\
\text { centroid } \\
\text { (m) }\end{array}$} & \multirow{2}{*}{$\begin{array}{l}\text { Percent- } \\
\text { age of } \\
\text { basin } \\
\text { above } \\
3,000 \mathrm{~m}\end{array}$} & \multicolumn{4}{|c|}{$\begin{array}{l}\text { Basinwide mean of monthly precipitation }{ }^{2} \\
(\mathrm{~mm})\end{array}$} & \multirow{2}{*}{$\begin{array}{l}\text { Percentage } \\
\text { of basin } \\
\text { consisting of } \\
\text { irrigated land }\end{array}$} \\
\hline & & & & & & $\begin{array}{l}\text { Octo- } \\
\text { ber }\end{array}$ & $\begin{array}{l}\text { Novem- } \\
\text { ber }\end{array}$ & $\begin{array}{l}\text { Decem- } \\
\text { ber }\end{array}$ & January & \\
\hline 334500069480000 & Gaber River near Chamkani & 465 & 36.6 & 2,620 & 22.4 & 13.6 & 23.0 & 39.0 & 58.6 & 2.93 \\
\hline 334600068210000 & $\begin{array}{l}\text { Barikab River above Seraj } \\
\text { Reservoir }\end{array}$ & 95.9 & 24.1 & 2,770 & 31.4 & 9.2 & 27.1 & 44.6 & 58.2 & 8.51 \\
\hline 334800069400000 & Khurram River at Doda & 1,050 & 33.5 & 2,750 & 31.6 & 14.5 & 27.4 & 44.6 & 65.5 & 6.94 \\
\hline 334800069480000 & Khurram River at Chamkani & 1,380 & 35.6 & 2,160 & 27.9 & 14.6 & 27.1 & 44.1 & 65.1 & 5.72 \\
\hline 334800069530000 & $\begin{array}{l}\text { Khurram River at Pul-i- } \\
\text { Bangakh }\end{array}$ & 1,960 & 35.4 & 1,910 & 25.1 & 14.5 & 25.8 & 42.5 & 63.3 & 5.26 \\
\hline 334900069230000 & Jilga River near Mechalghu & 60.6 & 30.7 & 2,880 & 67.6 & 12.2 & 27.5 & 45.6 & 64.2 & 0.00 \\
\hline 335000069390000 & Khurram River at Ahmadkhel & 723 & 33.3 & 2,250 & 34.4 & 14.9 & 27.5 & 44.6 & 65.9 & 6.49 \\
\hline 340500068450000 & Logar River at Shekhabad & 4,860 & 22.8 & 2,990 & 55.7 & 11.4 & 33.9 & 51.5 & 63.9 & 4.22 \\
\hline 340600068340000 & $\begin{array}{l}\text { Logar River above Band-i- } \\
\text { Chak Wardhak }\end{array}$ & 4,440 & 22.5 & 2,810 & 59.5 & 11.7 & 34.5 & 52.0 & 64.3 & 4.14 \\
\hline 340800064120000 & Kowgan River at Tangi Azu & 2,010 & 16.3 & 2,520 & 7.19 & 12.1 & 18.3 & 37.7 & 43.8 & 3.51 \\
\hline 341300063000000 & Kowgan River at Langar & 7,500 & 23.5 & 2,620 & 4.42 & 11.5 & 18.8 & 38.9 & 45.7 & 2.86 \\
\hline 341400066550000 & Punjab River at Waras & 1,700 & 32.6 & 3,060 & 73.2 & 14.3 & 27.7 & 32.3 & 39.1 & 3.54 \\
\hline 341400068300000 & Logar River at Kajab & 3,800 & 21.9 & 2,840 & 66.6 & 12.1 & 35.2 & 52.6 & 64.6 & 3.68 \\
\hline 341400071020000 & Kabul River at Dakah & 66,400 & 40.5 & 2,550 & 43.2 & 17.3 & 35.3 & 51.5 & 65.1 & 5.71 \\
\hline 341600062560000 & $\begin{array}{l}\text { Hari Rud River at Robat-i- } \\
\text { Akhond }\end{array}$ & 21,700 & 24.3 & 2,650 & 17.3 & 12.9 & 19.8 & 36.3 & 42.0 & 2.80 \\
\hline 342100063390000 & Hari Rud at Tagaw Ghaza & 11,900 & 24.5 & 2,280 & 28.3 & 13.6 & 20.4 & 33.6 & 38.5 & 1.93 \\
\hline 342100067290000 & $\begin{array}{l}\text { Markhana River at Dahane } \\
\text { Rishqa }\end{array}$ & 1,080 & 38.1 & 3,100 & 86.7 & 14.4 & 35.3 & 46.4 & 54.6 & 2.61 \\
\hline 342400069050000 & Kabul River at Tangi Saidan & 1,620 & 33.7 & 2,810 & 36.2 & 10.8 & 35.5 & 55.8 & 70.1 & 9.66 \\
\hline 342500069230000 & $\begin{array}{l}\text { Chakari River at Band-i-Amir } \\
\text { Ghazi }\end{array}$ & 388 & 24.1 & 2,340 & 21.4 & 12.7 & 33.0 & 51.0 & 70.7 & 2.99 \\
\hline
\end{tabular}


Appendix 1. Basin characteristics for streamgages used for estimation of streamflow at ungaged locations in mineral areas of interest in Afghanistan.

[USGS, U.S. Geological Survey; $\mathrm{km}^{2}$, square kilometers; m, meters; mm, millimeters]

\begin{tabular}{|c|c|c|c|c|c|c|c|c|c|c|}
\hline \multirow{2}{*}{$\begin{array}{l}\text { USGS streamgage } \\
\text { identification } \\
\text { number }\end{array}$} & \multirow{2}{*}{ Streamgage name } & \multirow{2}{*}{$\begin{array}{c}\text { Drainage } \\
\text { area }^{1} \\
\left(\mathbf{k m}^{2}\right)\end{array}$} & \multirow{2}{*}{$\begin{array}{l}\text { Mean } \\
\text { basin } \\
\text { slope } \\
\text { (percent) }\end{array}$} & \multirow{2}{*}{$\begin{array}{l}\text { Elevation } \\
\text { of basin } \\
\text { centroid } \\
\quad(\mathrm{m})\end{array}$} & \multirow{2}{*}{$\begin{array}{l}\text { Percent- } \\
\text { age of } \\
\text { basin } \\
\text { above } \\
3,000 \mathrm{~m}\end{array}$} & \multicolumn{4}{|c|}{$\begin{array}{l}\text { Basinwide mean of monthly precipitation }{ }^{2} \\
(\mathrm{~mm})\end{array}$} & \multirow{2}{*}{$\begin{array}{c}\text { Percentage } \\
\text { of basin } \\
\text { consisting of } \\
\text { irrigated land }\end{array}$} \\
\hline & & & & & & $\begin{array}{l}\text { Octo- } \\
\text { ber }\end{array}$ & $\begin{array}{l}\text { Novem- } \\
\text { ber }\end{array}$ & $\begin{array}{l}\text { Decem- } \\
\text { ber }\end{array}$ & January & \\
\hline 342500070180000 & Surkhrud River near Sultanpur & 2,610 & 31.2 & 2,970 & 29.2 & 18.3 & 27.7 & 42.7 & 68.5 & 9.50 \\
\hline 342600062280000 & Karukh River near Herat & 1,380 & 19.1 & 1,520 & 1.32 & 10.4 & 19.6 & 37.2 & 46.4 & 4.64 \\
\hline 342600069120000 & $\begin{array}{l}\text { Logar River at Sang-i- } \\
\text { Naweshta }\end{array}$ & 9,870 & 19.6 & 2,710 & 31.5 & 9.7 & 29.2 & 46.7 & 61.5 & 7.15 \\
\hline 342800070220000 & Kabul River near Daronta & 34,700 & 33.0 & 1,730 & 35.6 & 14.4 & 37.8 & 58.1 & 73.7 & 7.30 \\
\hline 342800070330000 & Konar River at Pul-i-Kama & 24,600 & 56.1 & 2,720 & 62.6 & 21.2 & 36.0 & 47.6 & 55.8 & 1.26 \\
\hline 343000068160000 & $\begin{array}{l}\text { Helmand River at } \\
\text { Gardandewal }\end{array}$ & 607 & 35.2 & 3,610 & 99.8 & 13.4 & 42.5 & 64.0 & 76.5 & 0.41 \\
\hline 343100065150000 & $\begin{array}{l}\text { Hari Rud River at } \\
\text { Chekhcheran }\end{array}$ & 6,110 & 25.2 & 2,740 & 48.9 & 14.0 & 21.7 & 28.7 & 33.6 & 2.19 \\
\hline 343300065460000 & Hari Rud River at Daulatyar & 2,880 & 28.8 & 2,720 & 58.2 & 14.9 & 23.9 & 28.2 & 32.7 & 2.12 \\
\hline 343300070140000 & $\begin{array}{l}\text { Laghman River at Pul-i- } \\
\text { Qarghai }\end{array}$ & 6,230 & 49.6 & 2,000 & 44.6 & 20.4 & 41.2 & 61.5 & 78.1 & 3.10 \\
\hline 343400068110000 & $\begin{array}{l}\text { Syahang River near } \\
\text { Gardandewal }\end{array}$ & 162 & 31.6 & 3,350 & 100 & 14.7 & 43.8 & 63.4 & 74.0 & 8.40 \\
\hline 343400069240000 & Kabul River at Tang-i-Gharu & 12,900 & 21.3 & 2,140 & 29.8 & 9.9 & 30.2 & 48.0 & 63.1 & 8.67 \\
\hline 343700069430000 & Kabul River at Naghlu & 26,500 & 30.0 & 2,310 & 36.1 & 12.9 & 38.4 & 59.3 & 73.9 & 8.63 \\
\hline 343800070490000 & Konar River near Konari & 23,400 & 57.1 & 2,120 & 65.5 & 21.5 & 37.3 & 49.0 & 56.2 & 0.99 \\
\hline 344000069410000 & Tagab River at Tagab & 793 & 38.4 & 1,970 & 19.0 & 14.9 & 36.0 & 54.4 & 73.4 & 7.26 \\
\hline 344500067000000 & Balkh River near Nayak & 1,450 & 24.0 & 3,020 & 90.5 & 15.9 & 37.1 & 45.5 & 51.2 & 1.18 \\
\hline 345000067490000 & Bamyan River at Bamyan & 964 & 23.0 & 3,120 & 83.8 & 15.7 & 40.7 & 54.4 & 61.3 & 3.03 \\
\hline 345300071100000 & Konar River near Asmar & 18,600 & 58.6 & 3,080 & 71.0 & 21.3 & 37.5 & 48.0 & 52.6 & 0.34 \\
\hline 345400071080000 & Pech River at Chaghasarai & 3,870 & 55.4 & 3,070 & 56.0 & 23.8 & 42.6 & 60.8 & 76.7 & 1.72 \\
\hline 350200064010000 & $\begin{array}{l}\text { Murghab River at Qala-i- } \\
\text { niazkhan }\end{array}$ & 13,800 & 28.7 & 2,770 & 18.1 & 14.0 & 20.0 & 37.9 & 42.0 & 0.71 \\
\hline
\end{tabular}


Appendix 1. Basin characteristics for streamgages used for estimation of streamflow at ungaged locations in mineral areas of interest in Afghanistan.

[USGS, U.S. Geological Survey; $\mathrm{km}^{2}$, square kilometers; m, meters; mm, millimeters]

\begin{tabular}{|c|c|c|c|c|c|c|c|c|c|c|}
\hline \multirow{2}{*}{$\begin{array}{l}\text { USGS streamgage } \\
\text { identification } \\
\text { number }\end{array}$} & \multirow{2}{*}{ Streamgage name } & \multirow{2}{*}{$\begin{array}{c}\text { Drainage } \\
\text { area }^{1} \\
\left(\mathrm{~km}^{2}\right)\end{array}$} & \multirow{2}{*}{$\begin{array}{l}\text { Mean } \\
\text { basin } \\
\text { slope } \\
\text { (percent) }\end{array}$} & \multirow{2}{*}{$\begin{array}{l}\text { Elevation } \\
\text { of basin } \\
\text { centroid } \\
\text { (m) }\end{array}$} & \multirow{2}{*}{$\begin{array}{c}\text { Percent- } \\
\text { age of } \\
\text { basin } \\
\text { above } \\
3,000 \mathrm{~m}\end{array}$} & \multicolumn{4}{|c|}{$\begin{array}{l}\text { Basinwide mean of monthly precipitation }{ }^{2} \\
(\mathrm{~mm})\end{array}$} & \multirow{2}{*}{$\begin{array}{c}\text { Percentage } \\
\text { of basin } \\
\text { consisting of } \\
\text { irrigated land }\end{array}$} \\
\hline & & & & & & $\begin{array}{l}\text { Octo- } \\
\text { ber }\end{array}$ & $\begin{array}{l}\text { Novem- } \\
\text { ber }\end{array}$ & $\begin{array}{l}\text { Decem- } \\
\text { ber }\end{array}$ & January & \\
\hline 350500069080000 & $\begin{array}{l}\text { Ghorband River at Pul-i- } \\
\text { Ashawa }\end{array}$ & 4,040 & 42.2 & 2,170 & 53.0 & 13.4 & 44.4 & 68.0 & 80.7 & 4.64 \\
\hline 350900069130000 & Salang River at Bagh-i-Lala & 488 & 48.3 & 2,900 & 46.0 & 15.1 & 49.3 & 80.2 & 93.6 & 4.19 \\
\hline 350900069170000 & Shatul River at Gulbahar & 202 & 48.5 & 3,250 & 63.9 & 16.8 & 52.6 & 85.5 & 99.4 & 0.72 \\
\hline 351000069170000 & Panjsher River at Gulbahar & 3,550 & 49.7 & 3,750 & 77.9 & 23.3 & 64.1 & 97.7 & 108.8 & 2.07 \\
\hline 351300062170000 & Kushk Riverat Chil Dukhtaran & 2,320 & 15.9 & 1,320 & 0.03 & 10.0 & 20.8 & 34.2 & 45.6 & 2.44 \\
\hline 351400063280000 & Bum River at Luka-i-Surkh & 1,240 & 16.3 & 1,410 & 0.16 & 17.2 & 20.5 & 45.0 & 47.8 & 0.67 \\
\hline 351600067590000 & Bamyan River at Doab & 5,030 & 32.8 & 4,060 & 61.9 & 14.7 & 41.4 & 57.1 & 64.9 & 3.11 \\
\hline 351800067550000 & Kunduz River at Dasht-i-Safed & 3,740 & 30.2 & 3,240 & 73.5 & 15.0 & 36.6 & 45.8 & 50.8 & 0.84 \\
\hline 352000062550000 & Kashan River at Babulai & 5,290 & 15.9 & 987 & 0.08 & 12.2 & 20.1 & 40.9 & 48.5 & 3.08 \\
\hline 352200069380000 & Panjsher River at Omarz & 2,230 & 48.7 & 2,850 & 87.3 & 25.5 & 67.9 & 100.6 & 109.8 & 1.34 \\
\hline 353500063190000 & $\begin{array}{l}\text { Murghab River at Bala } \\
\text { Murghab }\end{array}$ & 20,500 & 26.6 & 2,260 & 12.3 & 14.9 & 20.2 & 39.9 & 43.8 & 0.88 \\
\hline 353600068360000 & $\begin{array}{l}\text { Kunduz River at Pul-i-Konda } \\
\text { Sang }\end{array}$ & 12,600 & 35.4 & 2,420 & 59.7 & 14.3 & 40.9 & 56.6 & 64.0 & 2.01 \\
\hline 353600068410000 & Andarab River at Doshi & 3,740 & 43.7 & 2,410 & 38.7 & 16.0 & 51.3 & 81.7 & 93.0 & 3.93 \\
\hline 355600068430000 & Kunduz River at Pul-i-Khumri & 17,500 & 36.8 & 2,010 & 51.4 & 14.3 & 42.6 & 61.4 & 69.7 & 2.47 \\
\hline 355700064540000 & $\begin{array}{l}\text { Shirin Tagab River at Khisht } \\
\text { Pul }\end{array}$ & 3,240 & 24.2 & 1,360 & 2.05 & 11.5 & 19.9 & 36.1 & 42.9 & 2.82 \\
\hline 360600068400000 & Kunduz River at Baghlan & 19,800 & 35.3 & 1,330 & 46.3 & 13.8 & 41.5 & 59.5 & 67.7 & 3.16 \\
\hline 360800066570000 & Suf River near Kishandeh & 3,080 & 28.1 & 1,700 & 21.6 & 12.0 & 32.0 & 42.4 & 48.0 & 1.42 \\
\hline 361100066020000 & Shorab River near Sare Pul & 3,710 & 20.6 & 1,400 & 10.1 & 11.7 & 22.6 & 33.7 & 39.4 & 4.91 \\
\hline 361200065570000 & Sare Pul River at Asiabad & 7,100 & 22.7 & 1,920 & 14.3 & 12.4 & 22.9 & 35.1 & 40.5 & 3.84 \\
\hline 362200068520000 & Kunduz River at Gerdab & 23,000 & 33.2 & 1,210 & 40.2 & 13.3 & 39.9 & 56.9 & 65.0 & 4.27 \\
\hline
\end{tabular}


Appendix 1. Basin characteristics for streamgages used for estimation of streamflow at ungaged locations in mineral areas of interest in Afghanistan.

[USGS, U.S. Geological Survey; $\mathrm{km}^{2}$, square kilometers; m, meters; mm, millimeters]

\begin{tabular}{|c|c|c|c|c|c|c|c|c|c|c|}
\hline \multirow{2}{*}{$\begin{array}{l}\text { USGS streamgage } \\
\text { identification } \\
\text { number }\end{array}$} & \multirow{2}{*}{ Streamgage name } & \multirow{2}{*}{$\begin{array}{l}\text { Drainage } \\
\text { area } \\
\left(\mathrm{km}^{2}\right)\end{array}$} & \multirow{2}{*}{$\begin{array}{l}\text { Mean } \\
\text { basin } \\
\text { slope } \\
\text { (percent) }\end{array}$} & \multirow{2}{*}{$\begin{array}{l}\text { Elevation } \\
\text { of basin } \\
\text { centroid } \\
\quad(\mathrm{m})\end{array}$} & \multirow{2}{*}{$\begin{array}{l}\text { Percent- } \\
\text { age of } \\
\text { basin } \\
\text { above } \\
3,000 \mathrm{~m}\end{array}$} & \multicolumn{4}{|c|}{$\begin{array}{l}\text { Basinwide mean of monthly precipitation }{ }^{2} \\
(\mathrm{~mm})\end{array}$} & \multirow{2}{*}{$\begin{array}{l}\text { Percentage } \\
\text { of basin } \\
\text { consisting of } \\
\text { irrigated land }\end{array}$} \\
\hline & & & & & & $\begin{array}{l}\text { Octo- } \\
\text { ber }\end{array}$ & $\begin{array}{l}\text { Novem- } \\
\text { ber }\end{array}$ & $\begin{array}{l}\text { Decem- } \\
\text { ber }\end{array}$ & January & \\
\hline 362700064530000 & $\begin{array}{l}\text { Shirin Tagab River at } \\
\text { Daulatabad }\end{array}$ & 4,390 & 22.4 & 1,320 & 1.51 & 10.9 & 20.6 & 35.4 & 43.6 & 4.48 \\
\hline 363200064530000 & $\begin{array}{l}\text { Maimana River near Pata } \\
\text { Baba }\end{array}$ & 8,600 & 16.6 & 628 & 0.48 & 9.9 & 19.8 & 36.9 & 46.8 & 5.41 \\
\hline 363500064520000 & $\begin{array}{l}\text { Shirin Tagab River at Pata } \\
\text { Baba }\end{array}$ & 13,700 & 18.3 & 778 & 0.78 & 10.2 & 20.2 & 36.2 & 45.6 & 5.14 \\
\hline 363500066580000 & Balkh River at Rabat-i-Bala & 18,100 & 29.1 & 1,900 & 34.3 & 12.6 & 28.0 & 36.4 & 41.2 & 1.71 \\
\hline 363500067470000 & Khulm River at Sayad & 8,230 & 20.5 & 2,350 & 10.4 & 9.6 & 31.1 & 43.5 & 49.1 & 2.21 \\
\hline 363800069430000 & Farkhar River near Taloqan & 4,170 & 52.5 & 3,920 & 61.8 & 25.9 & 64.7 & 87.8 & 91.3 & 1.96 \\
\hline 364000067420000 & $\begin{array}{l}\text { Khulm River at Tangi } \\
\text { Tashqurghan }\end{array}$ & 8,280 & 20.7 & 2,370 & 10.3 & 9.5 & 31.0 & 43.3 & 48.9 & 2.23 \\
\hline 364200069150000 & Bangi River at Pul-i-Bangi & 4,480 & 42.2 & 1,780 & 29.3 & 16.7 & 46.8 & 69.7 & 78.1 & 5.40 \\
\hline 364400069120000 & Taloqan River at Pul-i-Chugha & 10,000 & 43.8 & 4,210 & 40.2 & 21.0 & 54.4 & 76.3 & 82.1 & 5.61 \\
\hline 365500070030000 & Keshem River near Keshem & 2,180 & 47.2 & 2,140 & 41.8 & 25.1 & 56.1 & 73.1 & 75.6 & 3.71 \\
\hline 365600070520000 & Kokcha River near Jurm & 7,770 & 55.9 & 2,830 & 80.4 & 32.5 & 73.4 & 91.5 & 90.6 & 1.25 \\
\hline 365700070030000 & Kokcha River near Keshem & 16,900 & 48.7 & 2,060 & 61.4 & 28.7 & 61.8 & 76.2 & 75.2 & 1.88 \\
\hline 365800070540000 & Warduj near Baharak & 3,380 & 50.3 & 4,700 & 85.8 & 29.5 & 61.9 & 73.8 & 70.9 & 1.64 \\
\hline 370100070500000 & Warduj River at Shashpul & 4,460 & 50.2 & 4,020 & 81.1 & 29.5 & 61.7 & 72.9 & 69.1 & 2.62 \\
\hline 370500069280000 & Kokcha River at Khojaghar & 20,900 & 46.7 & 3,470 & 54.2 & 27.2 & 58.6 & 72.8 & 72.9 & 1.94 \\
\hline
\end{tabular}

${ }^{1}$ Drainage area calculated by this study may differ from that reported by other studies.

${ }^{2}$ Precipitation estimates from Leemans and Cramer (1991). 
Prepared by the Pembroke and West Trenton Publishing Service Centers.

For more information concerning this report, contact:

Director

U.S. Geological Survey

New Hampshire-Vermont Water Science Center

331 Commerce Way, Suite 2

Pembroke, NH 03275

dc_nh@usgs.gov

or visit our Web site at:

http://nh.water.usgs.gov 
